\title{
The Influence of Procedural Fairness on Subsidiary Autonomy: The Mediating Roles of Knowledge Dependence
}

\author{
Canon Tong \\ International Graduate School of Business, University of South Australia \\ Adelaide SA, Australia \\ E-mail: canon.tong@unisa.edu.au \\ Stanley Kam-Sing Wong (Corresponding author) \\ Newcastle Graduate School of Business, University of Newcastle \\ Callaghan NSW, Australia \\ E-mail: stanleykswong@gmail.com \\ Anthony Wong \\ Newcastle Graduate School of Business, University of Newcastle \\ Callaghan NSW, Australia \\ E-mail: awong@cihe.edu.hk \\ Eddie Yiu-fai Kwok \\ Target Link Enterprises Limited, Hong Kong \\ E-mail: eddieyfkwok@hotmail.com
}

Received: August 22, 2011

Accepted: September 23, $2011 \quad$ Published: February 1, 2012

doi:10.5539/ass.v8n2p3

URL: http://dx.doi.org/10.5539/ass.v8n2p3

\begin{abstract}
This paper examines the effects of procedural fairness and knowledge dependence on the autonomy of multinational corporation's subsidiaries (subsidiary autonomy) in China. The originality of the paper lies in the identification and introduction of a new mediator, i.e., knowledge dependence, in the casual relationship between procedural fairness and subsidiary autonomy. Quantitative analysis shows that subsidiary autonomy is positively associated with procedural fairness. Knowledge dependence in terms of management expertise positively affects the level of subsidiary autonomy. Knowledge dependence in terms of technical know-how, however, is found to have insignificant effect on subsidiary autonomy. While it is found that high levels of perceived procedural fairness reinforces the dependence of management expertise in the parent-subsidiary dyadic, and which in turn increases the perceived level of subsidiary autonomy, the hypothesized mediating influence of the dependence of technical know-how in the dyadic relationship is, however, rejected.
\end{abstract}

Keywords: China subsidiaries, Subsidiary autonomy, Procedural fairness, Knowledge dependence, Dependence of management expertise, Dependence of technical know-how

\section{Introduction}

After 30 years of opening to the outside world, China has gained worldwide recognition for its economic achievements and has been very successful in attracting foreign investment. According to the Ministry of Commerce of the People's Republic of China (MOC, 2011), in 2010, despite continuing financial crisis in the West, the actual amount of foreign investment to China reached US\$ 106 billion, representing a $17 \%$ increase year-on-year. Although the implementation of tightening policy saw a slight decline in foreign investment, in the first six months of 2011, over 13 thousand new foreign companies established subsidiaries in China (China 
subsidiaries). New foreign direct investment (FDI) over the same period amounted to US\$60.89 billion. Remarkable growth was recorded in both the total amount of investment and individual investment per company.

In the days when China just opened its door, investments from Hong Kong which aimed at making good use of the low labour costs in China made up the majority of the FDIs. The ample opportunities that China offered soon attracted investments from Taiwan, Singapore and other Asian countries. FDIs not only brought in financial resources, but also technical know-how and management expertise. However, a significant change has taken place in recent years as more and more FDIs originating from non-Asian regions such as the USA and Europe are making their way into China. Most of them are multinational corporations (MNCs). However, with rising labour costs in China, foreign investments which are labour intensive are forced to adjust again by introducing changes to their modes of production and technological structures (China Daily, 2011).

Another notable change in FDI is that China is no longer regarded by MNCs as a purely manufacturing location. It is a R\&D centre (e.g. Honeywell's R\&D centres in Tianjin and Shanghai), customer service centre (e.g. GE's solution centre in Chengdu), regional headquarters (GE's Shanghai and Beijing regional headquarters) as well as a big, lucrative market. China is the biggest market for Volkswagen and the second biggest market for Nokia, Intel, Lucent, Samsung, LG, Philips and Kodak (Deng, 2005). Ever since China's accession to the World Trade Organisation (WTO), regulations and trading restrictions imposed by it on many industries have been lifted or relaxed, offering more opportunities for MNCs. This has substantially boosted the growth of China subsidiaries. To gain a better understanding of the power dynamics within a MNC, this study sought to examine how power-sharing and bargaining with their parent companies were perceived by the management of China subsidiaries.

Thirty years' of rapid economic development has radically altered the investment landscape of MNCs in China. China is the world's factory. The highly skilled and stable workforce there creates an environment that favours the development of China subsidiaries. The returns generated by these subsidiaries have also enhanced the competitiveness and profitability of MNCs as a whole. A subsidiary is defined in general as a company legally controlled by another company (the parent) which owns $50 \%$ or more of its shares. Being the principal stakeholder, the parent will always exercise a certain level of control over the subsidiary. The subsidiary, in return, will always be accountable to its parent at some level (Singh, 1972). However, this control and accountability relationship is governed, first of all, by concrete procedures, and secondly, is subject to the influence of diverse factors such as the perceived fairness of the procedures. Given China's unique investment environment, the relationship is further complicated by the local market, legal system, government and business practices, economic and cultural nuances experienced by the China subsidiaries. To most business ventures, China is a place of great opportunity. To seize these opportunities and to bring into full play the potential that it offers require agile business processes. Business agility implies autonomy and a study which examined the level of subsidiary autonomy as perceived by the subsidiaries themselves and the antecedents of such autonomy should arouse considerable interest in the academic and business communities.

Recent research on MNCs has shifted from a parent-centric perspective (Teece, 1986; Hymer, 1976) to a transnational network perspective (Yao and Xi, 2003; Zhao, 2002; Hedlund, 1993; Bartlett and Ghoshal, 1989; Hedland 1986; Perlmutter, 1969). Under the network perspective, the roles and functions of subsidiaries of MNCs have been extensively explored (Bartlett and Ghoshal, 1990; Porter, 1986). Some subsidiaries are developed to be specialized in certain functions, such as R\&D (Feinberg and Gupta, 2004; Phene and Almeida, 2008), others no longer play a submissive role but are created by their parents to achieve an international player or product mandate status (Roth and Morrison, 1992). With enhanced subsidiary competence, it becomes increasingly important for MNCs to capitalize on the knowledge and capability reside in their subsidiaries so as to facilitate leveraging of internal capacity from one node to other nodes of the global network (Feinberg and Gupta, 2004).

\subsection{Research Objectives}

Prior studies have identified several factors that could affect the autonomy of a subsidiary. They include the capabilities of a subsidiary, the complexity of the environment and the strategic importance of a subsidiary from the perspective of its parent (Bartlett and Ghoshal, 1989; Ghoshal and Nohria, 1989). Among these factors, resources have been identified as one of the key antecedent of subsidiary autonomy (Birkinshaw, 1997; Pfeffer and Salancik, 1978). It is common business sense that a subsidiary with heavy reliance on its parent's resources input enjoys less autonomy. Many prior studies have focused on the flow of tangible resources, such as financial resources, from a parent to a subsidiary. Little attention though has been given to the flow of intangible resources such as knowledge between the two parties. 
In today's rapidly evolving knowledge economy, the flow of knowledge between a parent and its subsidiary is a major determinant of business success (Gupta and Govindarajan, 1991, 2000; Ghoshal and Bartlett, 1988). While knowledge shared and transferred from a subsidiary to a parent allows the parent to tap into the wealth of expertise the subsidiary has accumulated and developed over a period of time, knowledge flow from a parent to a subsidiary represents strategic control and coordination of resources (Foss and Pedersen, 2004; Hutchings and Michailova, 2004). Despite the vital importance of this diffusion process, relatively less attention has been directed to investigate how this process is managed and what is the role of knowledge interdependence (Mahnke, Pedersen and Venzin, 2005) in the parent-subsidiary link. To fill this gap, this study examined the mediating effects of knowledge dependence on the relationship between procedural fairness and subsidiary autonomy in MNC settings in China.

Another gap identified is that most previous studies on subsidiary autonomy have been conducted in the developed countries (Birkinshaw, 1998; Roth and Morrison, 1992). There is a notable lack of research on the experience of subsidiaries operating in developing countries (Birkinshaw, 1998, 1997). In view of the growing importance of China as the world's biggest producer and consumer, a study which focused on subsidiary autonomy in China would certainly be of value to both academia and practitioners.

Three key constructs were featured in the proposed research model: procedural fairness; knowledge dependence and subsidiary autonomy. By way of application of quantitative analysis of data emanating from China, the study sought to ascertain, first of all, the existence of any casual relationships among the three constructs. Procedural fairness is the independent variable, subsidiary autonomy is the dependent variable and knowledge dependence is the mediator. In this study, four types of knowledge dependence were identified: a parent's dependence on a subsidiary's management expertise and technical know-how and a subsidiary's dependence of a parent's management expertise and technical know-how.

\section{Literature Review}

\subsection{Subsidiary autonomy}

Autonomy refers to the division of decision-making power between an organization and its subunits. Autonomous subunits are able to independently deploy the necessary resources to solve problems, seek out opportunities or create values (Garnier, 1982). Subsidiary autonomy is a complex issue which represents an on-going bargaining process between a parent and a subsidiary (Taggart and Hood, 1999). Subsidiary autonomy represents the decision-making power delegated by a parent to a subsidiary (Birkinshaw and Morrison, 1995; Taggart and Hood, 1999). Deferring to studies from scholars such as Taggart and Hood (1999), Birkinshaw and Morrison (1995), Garnier (1982), and Gates and Egelhoff (1986), this study defined subsidiary autonomy as: the degree of decision-making power authorized by a MNC to its subsidiaries.

Vachani (1999) posited that there is an inverse relationship between the level of a parent's control over its subsidiary and subsidiary autonomy. When a subsidiary makes all its decisions without consulting its parent, the subsidiary is said to have enjoyed the highest level of autonomy; when all decisions in a subsidiary are subject to the approval of its parent, it is then said to have enjoyed very low level or no autonomy at all.

Birkinshaw (1997) demonstrated that the concepts of heterarchy (Hedlund, 1986) and MNC network (Bartlett and Ghoshal, 1989) provide access to the concept of subsidiaries as semi-independent organizations in a diversified system. Within the context of a MNC network, some subsidiaries will necessarily have higher autonomy (Ghoshal and Nohria, 1989) and the varying degrees of autonomy exercised by a subsidiary can be explained by two broad perspectives. The first perspective suggests that the autonomy of a subsidiary should be determined by its parent, having regard to the capability, complexity of the operating environment and the strategic importance of the subsidiary concerned (Bartlett and Ghoshal, 1989; Ghoshal and Nohria, 1989). The second perspective argues that given autonomy is inherent in a parent-subsidiary relationship, to ensure that subsidiaries can build up its capability, they should be allowed to exercise their discretion and negotiate with their parents rather than simply passively accepting strategic roles assigned to them. Birkinshaw (1997) asserted that the above two points are complementary even if a parent recognizes that complete control is not possible or unnecessary. Therefore the right to autonomy and control is a trade-off between the two parties.

\subsection{Procedural Fairness}

The theory of procedure fairness, developed by Thibaut and Walker (1978), is a general theory of procedure for conflict resolution. Procedural fairness theory was used in management research to examine the decision-making process in a situation of imbalance of power, i.e., a situation where one party has decision-making power on issues that concern with and might affect the benefit of some other parties (Korsgaard, Schweiger and Sapienza, 
1995; Lind and Tyler, 1988). Procedures which are fair have six characteristics in common, namely consistency in application, bias-free decisions, information accuracy, correctability, representativeness and compatibility with fundamental moral and ethical values (Hassan and Hashim, 2011; Skarlicki and Folger, 1997) Studies have confirmed the association between the perceived level of procedural fairness of a decision and the behavioural outcome (Hassan and Hashim, 2011). Procedural fairness theory has been applied to MNC management research to understand how this type of fairness influences global strategies and the parent-subsidiary relationship (Chiang and Birtch, 2010; Kim and Mauborgne, 1993).

Procedural fairness is found to be positively associated with goal commitment (Kim and Mauborgne, 1993) and is critical to the formulation and implementation of a MNC's global strategies because MNC mangers care not only about what global strategies are being implemented, but also about how to formulate them. If managers of subsidiaries consider the process of global strategy formulation as impartial, they tend to act as positive implementers of strategies. Higher the degree of parent-subsidiary procedural fairness, greater will be the tendency for a parent to see that a subsidiary possesses more knowledge from local markets and hence more decision-making power will be delegated to the subsidiary. Meanwhile, if a subsidiary is empowered with the legitimacy to challenge the decision of its parent, it would be less likely for the parent to dominate the subsidiary, which in turn may result in higher subsidiary autonomy (Kim and Mauborgne, 1993). Therefore, the first hypothesis was:

\section{H1: Procedural fairness positively affects subsidiary autonomy.}

\subsection{Procedural Fairness and Knowledge Dependence}

Tangible and intangible resources are the two broad kinds of resources that a subsidiary may have to rely on the support of its parent (Gupta and Govindarajan, 1991; Pfeffer and Salancik, 1978). A subsidiary's dependence on its parent for tangible resources, especially at the start-up period, is obvious and there has been a plethora of literature on the influences of such a dependence in the parent-subsidiary relationship (Bouquet and Birkinshaw, 2008; Chen, Chen and $\mathrm{Ku}, 2011)$. Intangible resources, on the other hand, can be broadly categorized into technical know-how and management expertise (Roth and Morrison, 1992; Gupta and Govindarajan, 1991). While technical know-how refers to the knowledge and skills set an organization owns and that it needs to necessitate and facilitate the conversion of resources into new technologies, products, or services (Marquis, 1969; Wong and Tong, 2011), management expertise refers to the competencies of managers in running the business and leading the organization onto the road of success (Huck and McEwen, 1991).

Previous studies have found that a person's perception of procedural fairness in decision-making affects his work attitude (Schappe, 1996), including his willingness to share knowledge with others (Lin, 2006). This impact is felt not only at the individual level but also in the parent-subsidiary relationship (Kim and Mauborgne, 1993). If a subsidiary perceives that the a procedure is fair, i.e., it is given sufficient participation in the discussion leading to a decision, sufficient opportunity to present its case and communicate its feedback, then it will be more likely for the subsidiary to accept and adopt the management expertise and technical know-how from its parent. It will also be more enthusiastic for the subsidiary to share its own know-how and expertise with its parent and other subunits under the parent. High levels of perceived procedural fairness lead to increased communication, which may in turn facilitate both in-flow and out-flow of knowledge between a parent and a subsidiary. Therefore, it was hypothesized that:

\section{H2: Procedural fairness positively affects a subsidiary's dependence of its parent's management expertise.}

H3: Procedural fairness positively affects a subsidiary's dependence of its parent's technical know-how.

H4: Procedural fairness positively affects a parent's dependence of its subsidiary's management expertise.

\section{H5: Procedural fairness positively affects a parent's dependence of its subsidiary's technical know-how.}

\subsection{Knowledge Dependence and Subsidiary Autonomy}

Knowledge out-flow from a subsidiary to a parent, if managed well, enables the parent to build up knowledge stock and competence that may lead to informed and better decision-making, thus achieving high performance (Phene and Almeida, 2008). To tap into the knowledge stock of a subsidiary and to make that stock contributory to the MNC performance is a difficult challenge yet one that must be taken on by all MNCs if they wish to survive and thrive in the competitive global market. Knowledge in-flow from a parent to a subsidiary is also positive as this can enrich the global knowledge network by helping the subsidiary to build up capabilities necessary for its interaction with the parent as well as local operation (Mahnke et al., 2005). However, if a 
subsidiary is relying too much on knowledge out-flow from its parent, this may prevent the subsidiary from enjoying a high degree of autonomy (Gupta and Govindarajan, 1991, 1994). In other words, while knowledge resources may represent a main source of subsidiary power over its parent, if the subsidiary has no regulation over the in-flow of such resources from its parent, the in-flow of knowledge itself may turn into a form of control over the subsidiary. Therefore, it was hypothesized that:

H6: A subsidiary's dependence of its parent's management expertise negatively affects subsidiary autonomy.

H7: A subsidiary's dependence of its parent's technical know-how negatively affects subsidiary autonomy.

While it is necessary for a subsidiary to build up capabilities to acquire knowledge from its parent, the subsidiary must also build up knowledge absorption capabilities and establish a local network to gather and collect knowledge from the environment where it is operating (Mahnke et al., 2005). It should be noted that knowledge flow in a parent-subsidiary relationship is almost always bi-directional and sometimes the knowledge transferred may be diverted to contexts which lie beyond the corporate boundary (Phene and Almeida, 2008; Taggart and Hood, 1999). Geographically concentrated clusters can create knowledge which is useful and valuable to firms across a region (Phene and Almeida, 2008; Porter, 1998; Takahashi, 2009). Leading examples of such clusters include manufacturing clusters in the province of Guangdong in China and Johor of Malaysia, and R\&D clusters in San Jose, California and Zhong Guan Cun of China. R\&D is an expensive and high-risk business (Wong and Tong, 2011), if a MNC can make good use of the local knowledge where its subsidiary resides, the risk and cost of R\&D can be lowered. In other words, a subsidiary's access to local knowledge resources, i.e., the unique knowledge resources present in the location where its subsidiary is operating and if this knowledge is valuable to the MNC as a whole, the clustering effect so generated may confer on the subsidiary an knowledge advantage over its parent and/or other subsidiaries and hence a higher level of autonomy over the parent can be achieved (Phene and Almeida, 2008; Taggart and Hood, 1999). Therefore, it was hypothesized that:

H8: A parent's dependence of its subsidiary's management expertise positively affects subsidiary autonomy.

H9: A parent's dependence of its subsidiary's technical know-how positively affects subsidiary autonomy.

\subsection{Mediating Role of Knowledge Dependence}

High levels of perceived procedural fairness generate higher trust and commitment (Lind and Tyler, 1988). The procedural fairness theory has been applied extensively in the research of knowledge transfer and sharing in MNC setting (Chiang, Chang, Hsu and Wang, 2008; Luo, 2008). If a subsidiary management perceives a high level of procedural fairness in a decision-making process, the management will have greater intentions to accept and absorb the in-flow of decision-related knowledge from its parent (Chiang and Birtch, 2010; Kim and Mauborgne, 1993; Lind and Tyler, 1988). In other words, procedural fairness as perceived by a subsidiary increases a subsidiary's dependence on its parent's knowledge in-flow which may in turn decrease the autonomy of the subsidiary. Therefore, it was hypothesized that:

H10: The influence of procedural fairness on subsidiary autonomy is partially mediated by a subsidiary's dependence of management expertise from its parent.

H11: The influence of procedural fairness on subsidiary autonomy is partially mediated by a subsidiary's dependence of technical know-how from its parent.

On the other hand, if the management of a subsidiary perceives that there exists a high level of procedural fairness in a decision-making process, they will have higher intentions to support the decisions by sharing their knowledge with their parents (Chiang and Birtch, 2010; Kim and Mauborgne, 1993; Lind and Tyler, 1988). In other words, procedural fairness as perceived by a subsidiary will increase a parent's dependence on a subsidiary's knowledge out-flow which may in turn increase the autonomy of the subsidiary. Therefore, it was hypothesized that:

H12: The influence of procedural fairness on subsidiary autonomy is partially mediated a parent's dependence on management expertise from its subsidiary.

H13: The influence of procedural fairness on subsidiary autonomy is partially mediated a parent's dependence of technical know-how from its subsidiary. 


\section{Research model and Questionnaire}

Based on the literature reviewed, a research model was developed (Figure 1). The constructs in the model were adapted from the literature of various disciplines: the subsidiary autonomy construct was adapted from Birkinshaw, Hood and Jonsson (1998) and Vachani (1999); the procedural fairness construct was adapted from Kim and Mauborgne (1993); and the knowledge-related constructs were adapted from Roth and Morrison (1992), and Gupta and Govindarajan (1991). A seven-point Likert rating scale was used to measure all observable items in each construct.

$<$ Insert Figure 1 here $>$

\section{Methodology}

\subsection{Sampling Frame and Samples}

This research used quantitative methods to examine the interrelationships among the three key constructs of perceived procedural fairness, knowledge dependence and subsidiary autonomy. The database of this study was gathered from over 5,000 records contained in the List of Foreign Enterprises in China published by Dun and Bradstreet. In this study, the definition of a subsidiary followed that posited by Jarillo and Martinez (1990) but with the following additional criteria:

1) The parent must own at least $50 \%$ of the shares of its subsidiary;

2) The subsidiary must employ at least 50 people;

3) The subsidiary must have been operating in China for at least two years; and

4) The subsidiary must be in the manufacturing or other non-financial services sectors.

A survey website was created and 2,500 email invitations were sent to companies that met the criteria stated above to invite them to participate in the online survey.

E-mail invitations were sent to the CEOs and/or Managing Directors of MNC subsidiaries in China. The recipients of the invitations were invited to participate in the survey by visiting a website specially created for this study. The survey lasted for four weeks. By the end of the survey period, a total of 131 completed returns were received, representing a response rate of $5.24 \%$. The response rate was low but not unexpected since email addresses might have changed, the management structure and personnel might have changed, and most importantly, internet surveys are known to have response rates of no more than $10 \%$ (Malhotra, 2007). The companies that responded were China subsidiaries engaging in the manufacturing or non-financial services sectors. Financial institutions were excluded because the financial sector was in a turmoil due to the financial crisis that swept across the globe at the time of the survey.

\subsection{Data Analysis}

All observable items for each construct were adapted from scales used by prior research; it was, therefore, assumed that both validity and reliability of the scales should have been already established. For this reason, factor analysis procedures, exploratory and confirmatory, were not performed and reported in this study. However, in order to ensure the study quality, Cronbach's alpha test was conducted to confirm the internal consistency of the underlying variables (Coakes, Steed and Price, 2008; Wong and Tong, 2011). Regression analysis using SPSS was performed to determine the respective influences of a subsidiary's dependence of its parent's technical know-how and a subsidiary's dependence of its parent's management expertise on subsidiary autonomy; and also those of a parent's dependence of its subsidiary's technical know-how and a parent's dependence of its subsidiary's management expertise on subsidiary autonomy.

Descriptive statistics of the six variables were shown in Table 1 below. From the table, the respondents generally perceived a low level of procedural fairness (mean score $=2.98$ ) and subsidiary autonomy $(2.78)$. In the meantime, they perceived a high level of mutual technical dependence between the subsidiaries and their parents. The mean score of a parent's dependence on its subsidiary's technical know-how was 5.15 and that of a subsidiary's dependence on its parent's technical know-how was 4.64. However, the level of mutual management expertise dependence between subsidiaries and parents was perceived to be low. The mean score of a parent's dependence on its subsidiary's management expertise was 2.95 and that of a subsidiary's dependence on its parent's technical know-how was 2.90 .

$<$ Insert Table 1 here $>$ 


\section{Findings}

\subsection{Reliability}

Cronbach's alpha tests were conducted to test the internal consistency of the hypothesized variables (Coakes et al., 2008). As shown in Table 1, the Cronbach's alpha coefficients were in the range between 0.718 and 0.845 . Although the Cronbach's alpha values were low and that for perceived procedural fairness was as low as 0.718 , all of them were greater than the minimum acceptable limit of 0.7 (Nunnally, 1978), indicating that all variables had adequate internal consistency among their respective measuring items and suitable for further analysis.

\section{Hypotheses testing}

Results from the Cronbach's alpha coefficients indicated that the measuring scales and data were reliable and suitable for further tests. The correlations among the six variables were computed by using SPSS. Table 2 shows the standardized beta values and their significant levels. The variable of procedural fairness was found having a significantly $(\mathrm{p}<0.01)$ positive influence on subsidiary autonomy $(\mathrm{R}=0.799)$, giving support to H1. A subsidiary's dependence on its parent's management expertise was found to be significantly $(p<0.01)$ and positively influenced by procedural fairness $(\mathrm{R}=0.460)$, giving support to $\mathrm{H} 2$. Procedural fairness was found to have a weak, negative and insignificant ( $>0.05$ ) influence on a subsidiary's dependence on its parent's technical know-how (H3 was rejected) and a parent's dependence on its subsidiary's technical know-how (H5 was rejected). Parent's dependence on a subsidiary's management expertise was found to be significantly $(\mathrm{p}<0.01)$ and positively influenced by procedural fairness $(\mathrm{R}=0.282)$, giving support to $\mathrm{H} 4$.

A subsidiary's dependence on its parent's management expertise was hypothesized to be having a significantly negative influence on subsidiary autonomy. However, the regression analysis result revealed that a subsidiary's dependence on its parent's management expertise had a significantly $(\mathrm{p}<0.01)$ positive influence on subsidiary autonomy $(\mathrm{R}=0.533)$, rejecting H6. Subsidiary autonomy was found to have a weak, negative and insignificant $(p>0.05)$ influence on a subsidiary's dependence on its parent's technical know-how, rejecting H7. The influence of that on a parent's dependence on its subsidiary's technical know-how was similarly weak, negative and insignificant, therefore, rejecting H9. A parent's dependence on its subsidiary's management expertise was found to have a significant $(\mathrm{p}<0.01)$ and positive influence on subsidiary autonomy $(\mathrm{R}=0.359)$, giving support to $\mathrm{H} 8$.

$<$ Insert Table 2 here $>$

After examining the correlations among the variables, multiple regression analysis was used to find the regression formula and to test the hypotheses for $\mathrm{H} 10$ to $\mathrm{H} 13$ using the mediating procedure proposed by Baron and Kenny (1986). As shown in equation 1 of Table 3A, the independent variable of procedural fairness significantly influenced the dependent variable of subsidiary autonomy (Standardized beta $=0.799, \mathrm{p}<0.001$ ). In equation 2, procedural fairness significantly influenced the mediator of a subsidiary's dependence on its parent's management expertise (Standardized beta $=0.460, \mathrm{p}<0.001$ ). By adding the mediator, the influence of procedural fairness on subsidiary autonomy significantly $(\mathrm{p}<0.001)$ reduced from 0.799 in equation 1 to 0.702 in equation 3 . Also, the influence of the mediator on subsidiary autonomy was significant (Standardized beta $=0.210 ; \mathrm{p}<0.001$ ). All conditions in Baron and Kenny (1986) were fulfilled and, therefore, giving support to H10.

$<$ Insert Table 3A here $>$

As shown in equation 1 of Table $3 \mathrm{~B}$, the independent variable of procedural fairness significantly influenced the dependent variable of subsidiary autonomy (Standardized beta $=0.799, \mathrm{p}<0.001$ ). In equation 2 , procedural fairness insignificantly influenced the mediator of a subsidiary's dependence on its parent's technical know-how (Standardized beta $=-0.093, \mathrm{p}>0.05$ ). Since the second condition of Baron and Kenny (1986) was not fulfilled, H11 was rejected.

$<$ Insert Table 3B here $>$

As shown in equation 1 of Table $3 \mathrm{C}$, the independent variable of procedural fairness significantly influenced the dependent variable of subsidiary autonomy (Standardized beta $=0.799, \mathrm{p}<0.001$ ). In equation 2 , procedural fairness significantly influenced the mediator of a subsidiary's dependence on its parent's management expertise (Standardized beta $=0.282, \mathrm{p}<0.001$ ). By adding the mediator, the influence of procedural fairness on subsidiary autonomy significantly $(\mathrm{p}<0.001)$ reduced from 0.799 in equation 1 to 0.758 in equation 3 . Also, the influence of mediator on subsidiary autonomy was significant (Standardized beta $=0.146 ; \mathrm{p}<0.05$ ). All conditions of Baron and Kenny (1986) were fulfilled and, therefore, giving support to H12.

$<$ Insert Table 3C here $>$

As shown in equation 1 of Table 3D, the independent variable of procedural fairness significantly influenced the 
dependent variable of subsidiary autonomy (Standardized beta $=0.799, \mathrm{p}<0.001$ ). In equation 2, procedural fairness insignificantly influenced the mediator of a parent's dependence on its subsidiary's technical know-how (Standardized beta $=-0.053, \mathrm{p}>0.05$ ). The second condition of Baron and Kenny (1986) was not fulfilled and, therefore, $\mathrm{H} 13$ was rejected.

$<$ Insert Table 3D here $>$

\section{Discussion}

In today's highly competitive global market, a MNC's ability to maintain its competitive advantage depends very much on whether it can leverage the knowledge resided in its subsidiaries located across a number of geographical locations. This study which examined subsidiary autonomy of China subsidiaries and the casual relationships among subsidiary autonomy and its antecedents is important and meaningful to both the academic and business communities in the following aspects:

First of all, to the best knowledge of the authors, this study is believed to be the first study ever conducted to examine the mediating effects of four types of knowledge dependence, namely, a subsidiary's dependence on management expertise and technical know-how out-flow from its parent and a parent's dependence on management expertise and technical know-how out-flow from its subsidiary on the relationship between procedural fairness on subsidiary autonomy. The affirmation of the importance of procedure fairness on subsidiary autonomy and the low mean scores of procedural fairness and subsidiary autonomy as perceived by respondent subsidiaries in China should alert their parent managements of the need and urgency of making their strategic decision-making process more transparent. Higher transparency can allow management teams on-location to develop higher sense of empowerment, higher motivation to respond to parent decisions, and greater initiative to acquire local knowledge and share this knowledge with the parent and other subsidiaries.

The study hypothesized that a subsidiary's dependence on its parent's management expertise reduced the autonomy of the subsidiary (H6) and a parent's dependence on its subsidiary's management expertise increased subsidiary autonomy (H8). The findings of this study, however, revealed that dependence of management expertise, in either ways, is capable of increasing subsidiary autonomy. One possible explanation is that if one party in the parent-subsidiary dyadic relies heavily on the management expertise of the other party, such as knowledge about the manufacturing costs and exchange costs in China, the reliance will increase the mutual dependence of as well as knowledge sharing and communication between the two parties. The interdependence, knowledge sharing and the communication activities contribute positively to mutual trust and confidence which may in turn encourage the parent to give more autonomy to its subsidiary.

The study hypothesized that a subsidiary's dependence on its parent's technical know-how reduced the autonomy of the subsidiary (H7) and a parent's dependence on its subsidiary's technical know-how increased the autonomy of the subsidiary (H9). The findings of this study, however, rejected both hypotheses. Furthermore, the hypothesized mediating effects of interdependence of technical know-how (H11 and H13) were rejected, indicating that the level of perceived procedural fairness exerted no effect on such interdependence in the parent-subsidiary dyadic. One possible explanation to the above findings may be that the types of technology required by a subsidiary and a parent are actually very different and little synergy can be created between them. To illustrate, if a MNC has customer service centers in the USA and manufacturing plants in China, the technical know-how required by the two locations can be very different. The USA customer service centers may heavily rely on computer technology and IT systems to enhance their customer services productivity while the China manufacturing plants may heavily rely on metal processing technology and electro-plating technology to increase its manufacturing productivity. Therefore, no synergy can be created by sharing the technologies owned by the two.

The confirmation of the existence of mediating effects of interdependence of management expertise between a parent and a subsidiary (H10 and H12) indicated that high levels of perceived procedural fairness will reinforce such interdependence and which in turn will increase the perceived level of subsidiary autonomy. One explanation may possibly be that though management expertise is an all-inclusive component, knowledge flow of human resources management (HRM) which include, in particular, decisions on reward and movement of staff members, carries substantial weight in the exchange process. Higher the levels of procedural fairness, higher will be the intensity and frequency of such knowledge exchanges. In an organisational setting, nothing accelerates empowerment and general sense of self-efficacy than a fair and transparent HRM system. High levels of perceived procedural fairness mediated by interdependence of managerial expertise contribute to a subsidiary's perceived level of autonomy.

The findings have management implications for both parents and subsidiaries of MNCs. For the management of 
a parent, it is important for them to enhance procedural fairness in the decision-making process so that the subsidiary management will not develop any misperceived imbalance of power or unfairness. Domination of the parent and exclusionary decision-making may likely give rise and further aggrieve feelings of unfairness on the part of the subsidiary. These feelings, if not addressed promptly and effectively, may develop into parent-subsidiary conflicts which are harmful to the performance of the $\mathrm{MNC}$ as a whole. If the strategic decision-making process is transparent and subsidiaries are fully involved and consulted in decisions that affect their interests, the participatory process may enhance the subsidiaries' receptability to the decisions made.

High levels of perceived procedural fairness encourage subsidiaries to be more supportive and committed to implementing the decisions and see the benefits of adapting the knowledge resources, both managerial and technical, from their parents. Perceived procedural fairness will also encourage subsidiaries to share their knowledge resources with their parents and other subsidiaries. When a subsidiary is willing and ready to absorb and share knowledge, the knowledge stock of a MNC can be enriched and enhanced and a competitive edge can be formed. In other words, the mutual dependence of knowledge within the MNC facilitates knowledge management and application which may eventually boost the MNC's overall competitiveness.

The findings also have important implications for the management of subsidiaries. The positive influences of management expertise, revealed that subsidiaries should build up their capabilities to absorb knowledge resources available from their parents and other subsidiaries. Knowledge integration can enhance communication, minimize misunderstanding and hence reduce the chances of parent-subsidiary conflicts. Conflicts, if not handled properly, induce suspicion and aggression from the parent, which may eventually undermine subsidiary autonomy.

Subsidiary management should also develop their local knowledge, for example, knowledge relating to local legislation and local market situation, and share the knowledge within the MNC structure. The subsidiary's initiative to share such unique knowledge reinforces its parent's dependence on and hence its trust in the subsidiary. High levels of trust between parent and subsidiary encourage the parent to grant its subsidiary more autonomy. In other words, perceived procedural fairness increases the interdependence of knowledge, which in turn, enhances subsidiary autonomy.

\section{Limitation and Suggestion for Future Research}

While this research was aimed at providing a better understanding of the antecedents of subsidiary autonomy and the interplay among the antecedents and the consequent, it has some limitations. The research was conducted in the context of China subsidiaries of MNCs. The selection of sample may have led to the incorporation of some cultural-specific characteristics in the research findings. The model used in this research should be empirically tested in other countries in order to enhance its generalisability.

The cross-sectional nature of this study imposed the second limitation. As with other cross-sectional studies (e.g. Mak, Wong and Tong, 2011), this study could only capture and analyze a snapshot of a phenomenon and, therefore, failed to examine the change of participants' perception over time. Future research can be conducted on longitudinal basis to improve the reliability of results by tracking the changes in perceptions on procedural fairness and subsidiary autonomy over a considerable period of time.

The research was also limited by its use of a self-report questionnaire as it is impossible to clarify the meaning of questions. That may explain the relative low levels of response rate and Cronbach's alpha values of this study.

\section{References}

Baron, R. M. \& Kenny, D. A. (1986). The Moderator-Mediator Variable Distinction in Social Psychological Research: Conceptual, Strategic, and Statistical Considerations. Journal of Personality and Social Psychology, 51(6), 1173-1182. http://dx.doi.org/10.1037/0022-3514.51.6.1173

Bartlett, C. A. \& Ghoshal, S. (1989). Managing Across Borders: The Transnational Solution. Cambridge, Boston, MA: Harvard Business School Press.

Bartlett, C. A. \& Ghoshal, S. (1990). The Multinational Corporation as an Interorganizational Network. The Academy of Management Review, 15(4), 603-625.

Birkinshaw, J. (1997). Entrepreneurship in multinational corporations: The characteristics of subsidiary $\begin{array}{lllll}\text { initiatives. Strategic } & \text { Management } & \text { Journal, } & 18, & 207-229 \text {. }\end{array}$ http://dx.doi.org/10.1002/(SICI)1097-0266(199703)18:3<207::AID-SMJ864>3.0.CO;2-Q

Birkinshaw, J. (1998). Corporate entrepreneurship in network organizations: How subsidiary initiative drives internal market efficiency. European Management Journal, 16, 355-365. 
http://dx.doi.org/10.1016/S0263-2373(98)00012-7

Birkinshaw, J. M. \& Morrision, A. J. (1995). Configurations of strategy and structure in subsidiaries of multinational corporations. Journal of International Business Studies, 26(4), 729-753. http://dx.doi.org/10.1057/palgrave.jibs.8490818

Birkinshaw, J. M., Hood, N. \& Jonsson, S. (1998). Building firm-specific advantages in multinational corporations: The role of subsidiary initiative. Strategic Management Journal, 19, 221-241. http://dx.doi.org/10.1002/(SICI)1097-0266(199803)19:3<221::AID-SMJ948>3.0.CO;2-P

Bouquet, C. \& Birkinshaw, J. (2008). Managing Power in the Multinational Corporation: How Low-Power Actors Gain Influence. Journal of Management, 34(3), 477-508. http://dx.doi.org/10.1177/0149206308316062

Chen, T.J., Chen, H. \& Ku, Y.H. (2011). Resource dependency and parent-subsidiary capability transfers. Journal of World Business, In Press. http://dx.doi.org/10.1016/j.jwb.2011.04.013

Chiang, C.Y. Chang, S.C., Hsu, Y.W. \& Wang, Y.B. (2008). Parent-subsidiary links under procedural justice in the emerging market. International Journal of Commerce and Management, 18 (1), 60-76. http://dx.doi.org/10.1108/10569210810871498

Chiang, F.F.T. \& Birtch, T.A. (2010). Appraising Performance across Borders: An Empirical Examination of the Purposes and Practices of Performance Appraisal in a Multi-Country Context. Journal of Management Studies, 47(7), 1365-1393. http://dx.doi.org/10.1111/j.1467-6486.2010.00937.x

China Daily. (2011). Key Points of 2011 Government Work Report. [Online] Available: http://www.chinadaily.com.cn/language_tips/2011cpc/2011-03/24/content_12222717.htm (August 22nd, 2011)

Coakes, S. J., Steed, L. \& Price, J. (2008). SPSS Version 15.0 for Windows: Analysis without Anguish. Milton, Queensland: John Wiley \& Sons Australia, Ltd.

Deng, J. (2005). Transnational companies' twenty-year development in China. Merchants Weekly Journal, 44, 32-33.

Feinberg, S.E. \& Gupta, A.K. (2004). Knowledge spillovers and the assignment of R\&D responsibilities to foreign subsidiaries. Strategic Management Journal, 25, 823-845. http://dx.doi.org/10.1002/smj.396

Foss, N.J. \& Pedersen, T. (2004). Organizing knowledge processes in the multinational corporation: an introduction. Journal of International Business Studies, 35, 340-349. http://dx.doi.org/10.1057/palgrave.jibs. 8400102

Garnier, G. H. (1982). Context and decision making autonomy in foreign affiliates of U.S. multinational corporations. Academy of Management Journal, 25(4), 893-908. http://dx.doi.org/10.2307/256105

Gates, S. R. \& Egelhoff, W. G. (1986). Centralization in headquarters-subsidiary relationships. Journal of International Business Studies, 17(2), 71-92. http://dx.doi.org/10.1057/palgrave.jibs.8490425

Ghoshal, S. \& Bartlett, C. (1988). Creation, adoption and diffusion of innovations by subsidiaries of multinational corporations. Journal of International Business Studies, 19, 365-387. http://dx.doi.org/10.1057/palgrave.jibs.8490388

Ghoshal, S. \& Nohria, N. (1989). Internal differentiation within multinational corporations. Strategic Management Journal, 10(4), 323-338. http://dx.doi.org/10.1002/smj.4250100403

Gupta, A. K. \& Govindarajan, G. (1994). Organizing for knowledge flows within MNCs. International Business Reviews, 3(4), 443-457. http://dx.doi.org/10.1016/0969-5931(94)90033-7

Gupta, A. K. \& Govindarajan, G. (2000). Knowledge flows within multinational corporations. Strategic Management Journal, 21, http://dx.doi.org/10.1002/(SICI)1097-0266(200004)21:4<473::AID-SMJ84>3.0.CO;2-I

Gupta, A. K. \& Govindarajan, V. (1991). Knowledge flows and the structure of control within multinational corporations. Academy of Management Review, 16(4), 768-792. http://dx.doi.org/10.2307/258980

Hassan, A. \& Hashim, J. (2011). Role of organizational justice in determining work outcomes of national and expatriate academic staff in Malaysia. International Journal of Commerce and Management, 21(1), 82-93. http://dx.doi.org/10.1108/10569211111111711

Hedlund, G. (1986). The hypermodern MNC - a heterarchy? Human Resource Management, 25(1), 9-26. http://dx.doi.org/10.1002/hrm.3930250103 
Hedlund, G. (1993). Assumptions of hierarchy and heterarchy with applications to the management of the multinational corporation. In S.Ghoshal and D.S. Westney, (eds.), Organization Theory and the Multinational Corporation. New York: MachMillan.

Huck, J.F. \& McEwen, T. (1991). Competencies needed for small business success: perceptions of Jamaican entrepreneurs. Journal of Small Business Management, 29(2), 90-93.

Hutchings, K. \& Michailova, S. (2004). Facilitating knowledge sharing in Russian and Chinese subsidiaries: the role of personal networks and group membership. Journal of Knowledge Management, 8(2), 84-94. http://dx.doi.org/10.1108/13673270410529136

Hymer, S. H. (1976). The international operations of national firms: A study of direct foreign investment. Cambridge, Massachusetts: MIT Press.

Jarillo, J. C. \& Martinez, J. I. (1990). Different roles for subsidiaries: The case of multinational corporations in Spain. Strategic Management Journal, 11 (7), 501-512. http://dx.doi.org/10.1002/smj.4250110702

Kim, W. C. \& Mauborgne, R. (1993). Procedural justice, attitudes and subsidiary top management compliance with multinational's corporate strategic decisions. Academy of Management Journal, 36 (3), 502-526. http://dx.doi.org/10.2307/256590

Korsgaard, M.A., Schweiger, D.M. \& Sapienza, H.J. (1995). Building Commitment, Attachment, and Trust in Strategic Decision-Making Teams: The Role of Procedural Justice. The Academy of Management Journal, 38 (1), 60-84. http://dx.doi.org/10.2307/256728

Lin, C.P. (2006). Gender differs: Modelling knowledge sharing from a perspective of social network ties. Asian Journal of Social Psychology, 9 (3), 236-241. http://dx.doi.org/10.1111/j.1467-839X.2006.00202.x

Lind E.A. \& Tyler, R.R. (1988). The social psychology of procedural justice. New York: Plenum Press.

Luo, Y. (2008). Procedural fairness and interfirm cooperation in strategic alliances. Strategic Management Journal, 29 (1), 27-46. http://dx.doi.org/10.1002/smj.646

Mahnke, V., Pedersen, T. \& Venzin, M. (2005). The impact of knowledge management on MNC subsidiary performance: the role of absorptive capacity. Management International Review, 45 (2), 101-119.

Mak, K., Wong, S.K.S. \& Tong, C. (2011). How Guanxi Influences Word of Mouth Intentions, International Journal of Business Management, 6 (7), 3-14. http://dx.doi.org/10.5539/ijbm.v6n7p3

Malhotra, N. K. (2007). Marketing Research: An Applied Orientation (5 $5^{\text {th }}$ ed.). Upper Saddle River, New Jersey: Prentice Hall.

Marquis, D. (1969). The anatomy of successful innovations. Innovation, 1 (1), 35-48.

MOC. (2011). Statistics, Ministry of Commerce, People's Republic of China [Online] Available: http://english.mofcom.gov.cn/statistic/statistic.html (20 ${ }^{\text {th }}$ August, 2011)

Nunnally, J. C. (1978). Psychometric Theory. New York: McGraw-Hill.

Perlmutter, H. V. (1969). The tortuous evolution of the multinational corporation. Columbia Journal of World Business, 4, 9-18.

Pfeffer, J. \& Salancik, G.R. (1978). The External Control of Organizations: A Resource Dependence Perspective. New York: Harper \& Row.

Phene, A. \& Almeida, P. (2008). Innovation in multinational subsidiaries: The role of knowledge assimilation and subsidiary capabilities. Journal of International Business Studies, 39 (5), 901-919. http://dx.doi.org/10.1057/palgrave.jibs.8400383

Porter, M. E. (1986). Competition in Global Industries. Boston: Harvard Business School Press.

Porter, M.E. (1998). The Competitive Advantage of Nations. New York: Free Press.

Roth, K. \& Morrison, A. J. (1992). Implementing global strategy: Characteristics of global subsidiary mandate. Journal of International Business Studies, 23 (4), 715-735. http://dx.doi.org/10.1057/palgrave.jibs.8490285

Schappe, S.P. (1996). Bridging the Gap between Procedural Knowledge and Positive Employee Attitudes Procedural Justice as Keystone. Group Organization Management, 21 (3), 337-364. http://dx.doi.org/10.1177/1059601196213005

Singh, A. (1972). Holding Company and the Public Sector: An Instrument of State Enterprise. Economic and Political Weekly, 7 (30), 1415-1423. 
Skarlicki, D.P. \& Folger, R. (1997). Retailiation in the Workplace: The Roles of Distributive, Procedural and Interactional Justice. Journal of Applied Psychology, $82 \quad$ (3), $434-443$. http://dx.doi.org/10.1037//0021-9010.82.3.434

Taggart, J. H. \& Hood, N. (1999). Determinants of autonomy in multinational corporation subsidiaries. European Management Journal, 17, 226-236. http://dx.doi.org/10.1016/S0263-2373(98)00081-4

Takahashi, T. (2009). Absorptive Capacity of Multinational Subsidiary in Intra-Firm Knowledge Transfer: Cases from Japanese Multinational Manufacturers. International Journal of Global Business and Competitiveness, 4 (1), 31-42.

Teece, D. J. (1986). Transaction cost economics and the multinational enterprise. Journal of Economic Behavior and Organization, 7 (1), 21-45. http://dx.doi.org/10.1016/0167-2681(86)90020-X

Thibaut, J. \& Walker, L. (1978). A Theory of Procedure. California Law Review, 66 (3), $541-566$. http://dx.doi.org/10.2307/3480099

Vachani, S. (1999). Global diversification's effect on multinational subsidiaries' autonomy. Journal of International Business Studies, 8, 535-560. http://dx.doi.org/10.1016/S0969-5931(99)00019-0

Wong, S.K.S. \& Tong, C. (2011). The Influence of Market Orientation on New Product Success. European Journal of Innovation Management. 15(1), [EarlyCite version] In Press.

Yao, X.T. \& Xi, Q. M. (2003). Social network theory and its application in the enterprise research. Journal of $X i$ 'an Jiaotong University, 23(3), 22-27.

Zhao, J. H. (2002). Strategic study of MNCs in China. Journal of Management World, 10, 93-101.

Table 1. Descriptive Statistics

\begin{tabular}{|l|c|c|c|c|}
\hline & Mean & $\begin{array}{c}\text { Std. } \\
\text { Deviation }\end{array}$ & $\begin{array}{c}\text { Cronbach's } \\
\text { Alpha }\end{array}$ & $\begin{array}{c}\text { Number of } \\
\text { Items }\end{array}$ \\
\hline Subsidiary Autonomy & 2.78 & 0.801 & 0.770 & 9 \\
\hline $\begin{array}{l}\text { Subsidiary's Dependence on Parent's } \\
\text { Management Expertise }\end{array}$ & 2.95 & 1.101 & 0.845 & 4 \\
\hline $\begin{array}{l}\text { Subsidiary's Dependence on Parent's Technical } \\
\text { Know-How }\end{array}$ & 5.15 & 0.976 & 0.800 & 4 \\
\hline $\begin{array}{l}\text { Parent's Dependence on Subsidiary's } \\
\text { Management Expertise }\end{array}$ & 2.90 & 0.993 & 0.775 & 4 \\
\hline $\begin{array}{l}\text { Parent's Dependence on Subsidiary's Technical } \\
\text { Know-How }\end{array}$ & 4.64 & 0.997 & 0.756 & 4 \\
\hline Procedural Fairness & 2.98 & 0.854 & 0.718 & 4 \\
\hline
\end{tabular}

Table 2. Linear Regression Analysis Results

\begin{tabular}{|l|c|c|}
\hline & Procedural fairness & Subsidiary Autonomy \\
\hline Procedural fairness & 1 & $0.799 * *$ \\
\hline $\begin{array}{l}\text { Subsidiary's Dependence on Parent's } \\
\text { Management Expertise }\end{array}$ & $0.460 * *$ & $0.533^{* *}$ \\
\hline $\begin{array}{l}\text { Subsidiary's Dependence on Parent's Technical } \\
\text { Know-How }\end{array}$ & $-0.093(\mathrm{~ns})$ & $-0.111(\mathrm{~ns})$ \\
\hline $\begin{array}{l}\text { Parent's Dependence on Subsidiary's } \\
\text { Management Expertise }\end{array}$ & $0.282 * *$ & $0.359 * *$ \\
\hline $\begin{array}{l}\text { Parent's Dependence on Subsidiary's Technical } \\
\text { Know-How }\end{array}$ & $-0.053(\mathrm{~ns})$ & $-0.073(\mathrm{~ns})$ \\
\hline
\end{tabular}


Table 3A. Mediating Effect of Subsidiary's Dependence on Parent's Management Expertise

\begin{tabular}{|l|l|c|c|c|}
\hline \multicolumn{2}{|l|}{ Equation } & 1 & 2 & 3 \\
\hline \multicolumn{2}{|l|}{ Dependent Variable: } & $\begin{array}{c}\text { Subsidiary } \\
\text { Autonomy }\end{array}$ & $\begin{array}{c}\text { The } \\
\text { Mediator }\end{array}$ & $\begin{array}{c}\text { Subsidiary } \\
\text { Autonomy }\end{array}$ \\
\hline \multirow{2}{*}{$\begin{array}{l}\text { Independent } \\
\text { Variable(s): }\end{array}$} & Procedural Fairness & $0.799 * *$ & $0.460 * *$ & $0.702 * *$ \\
\cline { 2 - 5 } & The Mediator & - & - & $0.210^{* *}$ \\
\hline
\end{tabular}

Note: $* *: \mathrm{p}<0.001$

Note: $* *: p<0.001$

Table 3B. Mediating Effect of Subsidiary’s Dependence on Parent's Technical Know-How

\begin{tabular}{|l|l|c|c|c|}
\hline \multicolumn{2}{|l|}{ Equation } & 1 & 2 & 3 \\
\hline \multirow{2}{*}{ Dependent Variable: } & $\begin{array}{c}\text { Subsidiary } \\
\text { Autonomy }\end{array}$ & $\begin{array}{c}\text { The } \\
\text { Mediator }\end{array}$ & $\begin{array}{c}\text { Subsidiary } \\
\text { Autonomy }\end{array}$ \\
\hline $\begin{array}{l}\text { Independent } \\
\text { Variable(s): }\end{array}$ & Procedural Fairness & $0.799 * *$ & $-0.093(\mathrm{~ns})$ & $0.795^{* *}$ \\
\cline { 2 - 5 } & The Mediator & - & - & $-0.037(\mathrm{~ns})$ \\
\hline
\end{tabular}

Note: $* *: \mathrm{p}<0.001$; ns: $\mathrm{p}>0.05$.

Table 3C. Mediating Effect of Parent's Dependence on Subsidiary's Management Expertise

\begin{tabular}{|l|l|c|c|c|}
\hline \multicolumn{2}{|l|}{ Equation } & 1 & 2 & 3 \\
\hline \multicolumn{2}{|l|}{ Dependent Variable: } & $\begin{array}{c}\text { Subsidiary } \\
\text { Autonomy }\end{array}$ & $\begin{array}{c}\text { The } \\
\text { Mediator }\end{array}$ & $\begin{array}{c}\text { Subsidiary } \\
\text { Autonomy }\end{array}$ \\
\hline \multirow{2}{*}{$\begin{array}{l}\text { Independent } \\
\text { Variable(s): }\end{array}$} & Procedural Fairness & $0.799^{* *}$ & $0.282^{* *}$ & $0.758^{* *}$ \\
\cline { 2 - 5 } & The Mediator & - & - & $0.146^{*}$ \\
\hline
\end{tabular}

Note: $* *: p<0.001 ; *: p<0.05 ; \mathrm{ns}: \mathrm{p}>0.05$.

Table 3D. Mediating Effect of Parent's Dependence on Subsidiary's Technical Know-How

\begin{tabular}{|l|l|c|c|c|}
\hline \multicolumn{2}{|l|}{ Equation } & 1 & 2 & 4 \\
\hline \multirow{2}{*}{ Dependent Variable: } & $\begin{array}{c}\text { Subsidiary } \\
\text { Autonomy }\end{array}$ & $\begin{array}{c}\text { The } \\
\text { Mediator }\end{array}$ & $\begin{array}{c}\text { Subsidiary } \\
\text { Autonomy }\end{array}$ \\
\hline $\begin{array}{l}\text { Independent } \\
\text { Variable(s): }\end{array}$ & Procedural Fairness & $0.799 * *$ & $-0.053(\mathrm{~ns})$ & $0.797 * *$ \\
\cline { 2 - 5 } & The Mediator & - & - & $-0.031(\mathrm{~ns})$ \\
\hline
\end{tabular}

Note: $* *: p<0.001 ; \mathrm{ns}: \mathrm{p}>0.05$. 


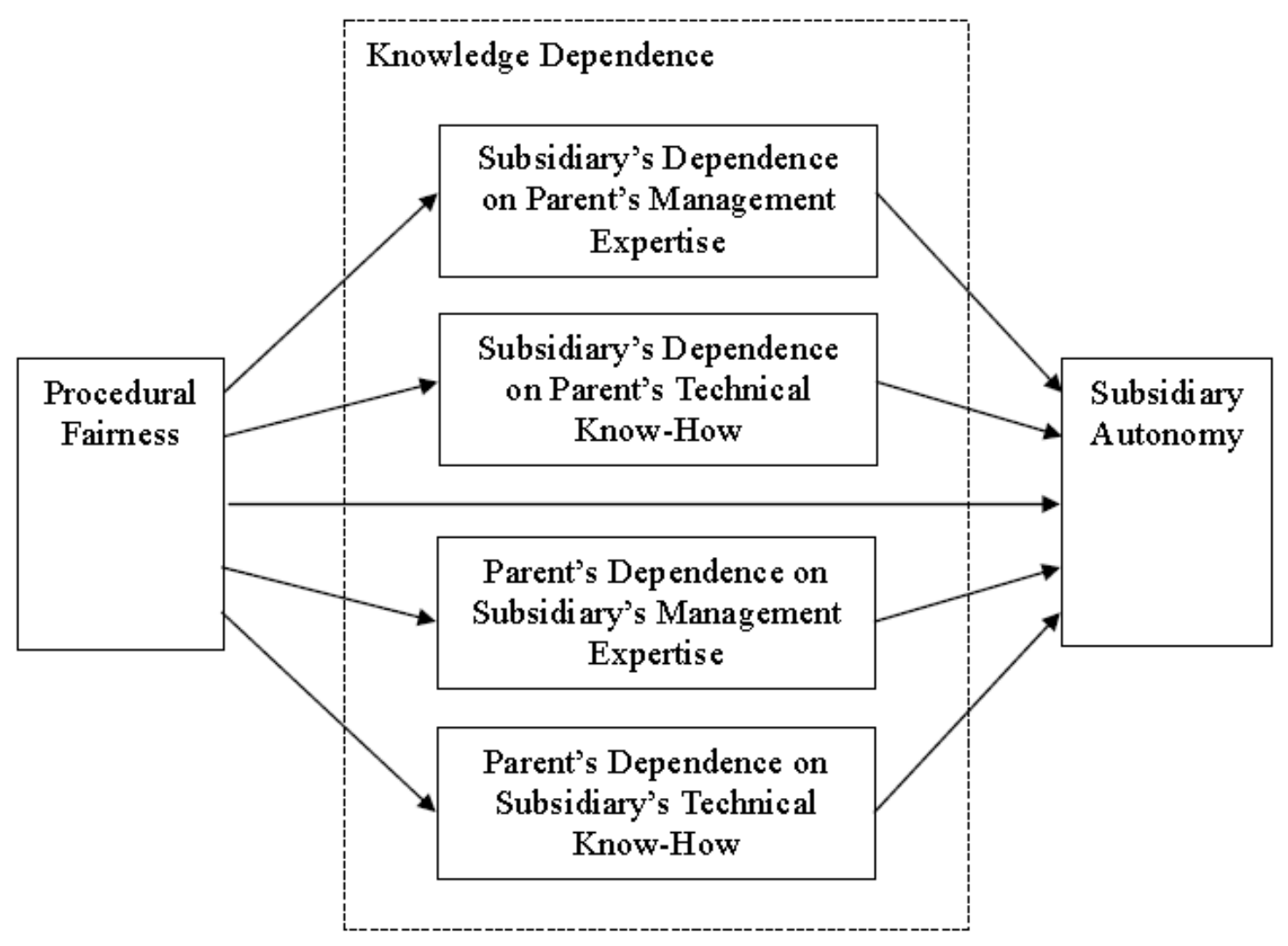

Figure 1. Research Model 